\section{Drought Resistance Strategies of Seashore Paspalum Cultivars at Different Mowing Heights}

\author{
Mohamed A. Shahba ${ }^{1,2}$ and Mohamed S. Abbas \\ Department of Natural Resources, Institute of African Research and Studies, \\ Cairo University, Giza, Egypt 12613
}

\section{Saad F. Alshammary \\ Center of Agriculture Technology, King Abdulaziz City for Science and Technology, Riyadh, Saudi Arabia}

Additional index words. 'Adalayd', drought tolerance, 'Excalibur', mowing height, 'Salam'

Abstract. Understanding how mowing height and soil moisture influence drought resistance mechanisms may lead to better management of seashore paspalum. This research was conducted to evaluate the effect of mowing height and soil moisture replacement on drought tolerance strategies in three seashore paspalum cultivars. In a greenhouse, clear polyvinyl chloride (PVC) root tubes were placed in a black PVC sleeve with a bottom cap drilled with holes for drainage. Sod pieces $(10 \mathrm{~cm}$ in diameter) of seashore paspalum (Paspalum vaginatum Swartz) cultivars Salam, Excalibur, and Adalayd were planted into these tubes after roots were trimmed. In a split-split experimental design, water regimes applied included control $[100 \%$ of the total evapotranspiration (ET)] as well as $75 \%, 50 \%$, and $25 \%$ of the total ET. Mowing heights were 45.0, 35, and $25 \mathrm{~mm}$. Visual turf quality, maximum root extension (MRE), root length densities (RLD), total nonstructural carbohydrate content (TNC), shoot reducing sugar content (RSC), and proline content were determined. Turf quality decreased linearly with the decrease in irrigation water applied under the three mowing heights with higher slope at $25.0 \mathrm{~mm}$ than at either $35.0 \mathrm{or}$ $45.0 \mathrm{~mm}$. 'Salam' turf quality declined only to the unacceptable rating of 5.5 and 4.5 when mowed to 35 and $25 \mathrm{~mm}$, respectively, whereas quality was 6.5 at the mowing height of $45 \mathrm{~mm}$ under the water regime of $25 \%$ of total ET. 'Excalibur' did not show acceptable turf quality at the $\mathbf{2 5 \%}$ treatment, whereas 'Adalayd' did not show such quality at both $\mathbf{5 0 \%}$ and $25 \%$ water regimes under all mowing heights. Regression analysis indicated a significant negative association between RLD and drought levels at all mowing heights and soil depths. In 'Salam', as drought levels increased from control to $25 \%$, average RLD decreased by $76 \%, 75 \%$, and $76 \%$ at $25-, 35-$, and $45-\mathrm{mm}$ mowing heights, respectively, at the top $30 \mathrm{~cm}$ of soil in the column. The change was $93 \%, 85 \%$, and $83 \%$ at $25-, 35-$, and 45-mm mowing heights, respectively, at the deeper soil $(90$ to $120 \mathrm{~cm})$. In 'Salam', on average overall water regimes, MRE at $45 \mathrm{~mm}$ was $\approx 10 \%$ to $17 \%$ greater than that of $35-\mathrm{mm}$ mowing height and $28 \%$ to $36 \%$ greater than that of $25-\mathrm{mm}$ mowing height. The highest root mass $(810 \mathrm{mg})$ was obtained when 'Salam' was mowed to $45 \mathrm{~mm}$ and subjected to the drought level of $50 \%$ of the total ET. The lowest root mass $(320 \mathrm{mg})$ was obtained when 'Salam' was mowed to $25 \mathrm{~mm}$ and the water regime was not limiting. In 'Salam', as drought increased from control to $25 \%$ of the total ET, average TNC decreased by $43.5 \%, 26.0 \%$, and $29.0 \%$ and the average TNC decrease in 'Excalibur' shoots was $48.0 \%, 30.0 \%$, and $32.0 \%$, whereas the decrease in 'Adalayd' was $51.3 \%, 42.3 \%$, and $35.4 \%$ at 25-, 35-, and 45-mm mowing heights, respectively. As drought levels increased from control to $25 \%$ of the total ET, average RSC increased by $57.3 \%, 57.1 \%$, and $53.0 \%$ in 'Salam' and by 59.4\%, 57.0\%, and 51.5\% in 'Excalibur' and $61.2 \%, 58.1 \%$, and $61.0 \%$ in 'Adalayd' at 25-, 35-, and 45-mm mowing height, respectively. When drought increased to $25 \%$, average proline content in shoots increased by $435 \%, 432 \%$, and $431 \%$ in 'Salam'; $404 \%, 376 \%$, and 324\% in 'Excalibur'; and 257\%, 278\%, and 302\% in 'Adalayd', at 25-, 35-, and 45-mm mowing heights. The resistance of paspalum cultivars to moderate to high drought stress can be enhanced by increasing the mowing height that may be related to increased carbon fixation, which favors increased root production. Proline accumulation could add to the drought tolerance through osmoregulation or by acting as a carbon and nitrogen sink for stress recovery.

\footnotetext{
Received for publication 27 Aug. 2013. Accepted for publication 9 Dec. 2013

${ }^{1}$ Current address: Department of Horticulture and Landscape Architecture, Colorado State University, Fort Collins, CO 80523-1173.

${ }^{2}$ To whom reprint requests should be addressed; e-mailshahbam@lamar.colostate.edu.
}

The demand for water has increased more than $300 \%$ during the past five decades (Huffman, 2004). Therefore, the development of efficient irrigation management programs as well as the improvement of drought resistance of turfgrasses has become extremely important to maintain quality turfgrass.
To reduce water use on turf, it is important to understand the mechanisms of plant adaptation to drought stress in various turfgrass species. Drought resistance includes a range of mechanisms used by plants to withstand periods of drought (Beard, 1989). Strategic mechanisms include drought escape, drought avoidance, and drought tolerance (Turner, 1986). The significance of each of these strategies is related to drought duration and severity in addition to the grass species. These mechanisms are associated with anatomical, morphological, physiological, and biochemical changes. Turfgrasses often concentrate their roots in the upper $30 \mathrm{~cm}$ (Beard, 1982). Turfgrasses may resist drought through developing deeper root systems and possessing shoot morphological or physiological mechanisms that reduce ET losses (Beard, 1989). Usually turf quality and ET rate have been used to evaluate drought resistance in turfgrasses (Ebdon and Petrovic, 1997). Root viability and deep rooting have received less attention as criteria to evaluate drought resistance although they have great importance (Huang et al., 1997; White et al., 1992). Deeper and greater root mass and a wider distribution of roots facilitate greater water extraction from the soil (Qian et al., 1997). Changes in leaves that facilitate drought resistance include reduced leaf growth and area, increased pubescence, rolling or folding, and fewer stomates (Duncan and Carrow, 1999).

It has been reported that paspalum has a low water requirement, a moderate fertility requirement, and resistance to mowing at a range of heights in addition to its superior salinity and drought resistance (Marcum and Murdoch, 1990; Shahba, 2010a). These characteristics make seashore paspalum a good alternative warm-season turfgrass such as Cynodon dactylon Pers. (bermudagrass), Zoysia japonica Steud. (zoysiagrass), and Stenotaphrum secundatum Walt. (st. augustinegrass) for arid and semiarid environments. Zinn (2004) reported that under efficient management, paspalum would use $50 \%$ less water than bermudagrass. In contrast, Bañuelos et al. (2011) found that bermudagrasses performed better than seashore paspalums at the lowest irrigation levels through enhanced turf recovery, higher quality ratings, higher dry matter production, and lower canopy-air temperature differentials when comparing 'Tifsport', 'Tifway 419', 'Tifgreen 328', and 'MidIron' bermudagrass [Cynodon dactylon (L.) Pers. $\times$ Cynodon transvaalensis Davy] and 'SeaSpray', 'SeaDwarf', and 'Sea Isle 1' seashore paspalum (Paspalum vaginatum Swartz) under different irrigation levels in Arizona.

Turfgrass species, and cultivars within a species, vary in their stress resistance. These variations often are the result of genetic variations, especially in genes relating to drought resistance mechanisms and their interaction with environments (Duncan and Carrow, 1999). Seashore paspalum has considerable interspecific diversity for various environmental stresses such as salinity, drought, 
wear, pests, and soil acidity (Duncan, 1999; Lee et al., 2004c; Trenholm et al., 1999).

The balance between carbohydrate production and consumption will impact the ability of turfgrass species to cope with stresses (Huang and Fry, 1999; Lee et al., 2008a, 2008b; Shahba, 2010b). Amino acids, especially proline, accumulate in larger amounts to cope with increasing stress in plants (Lee et al., 2008b). Proline accumulation is one of the first responses of plants exposed to water deficit stress and serves to reduce injury to cells (Ashraf and Foolad, 2007). Rapid accumulation of proline in tissues of many plant species in response to drought, salt, or temperature stresses has been attributed to enzyme stabilization and/ or osmoregulation (Flowers et al., 1977; Levitt, 1980). However, because of contrasting reports related to proline accumulation effect on stress tolerance (Marcum, 2002; Torello and Rice, 1986), its use as a selection criterion for stress tolerance has been questioned (Ashraf and Harris, 2004). Thus, it is critical that tests be made before making any conclusion regarding the role of proline in stress tolerance of any specific species.

Turfgrass managers have suggested a mowing height range of 25 to $50 \mathrm{~mm}$ for seashore paspalum cultivars. However, mowing at $25 \mathrm{~mm}$ or less is a better option because the reduction in mowing height increases turf density and produces plants with shorter internodes. Mowing heights above $50 \mathrm{~mm}$ reduce turfgrass density and increase thatch (Brosnan and Deputy, 2009; Lee et al., 2002, 2004b)

Shahba (2010a) and Shahba et al. (2012) concluded that salinity resistance of paspalum cultivars can be enhanced by increasing mowing height. Currently there is no published information that addresses the influence of mowing height and frequency on seashore paspalum drought resistance and rooting characteristics. Knowledge of these effects should help to identify physiological factors involved in drought and close mowing tolerance, which in turn should lead to better management of seashore paspalum turf sites. The objectives of this study were to 1) examine the drought resistance of seashore paspalum cultivars at three mowing heights; 2) to investigate differences in root characteristics and activity in response to soil moisture extraction patterns and ET rate; 3) examine the mechanisms associated with drought resistance such as proline content, TNC, RSC, $\mathrm{ET}$ rates, and rooting characteristics.

\section{Materials and Methods}

\section{Plant materials and growth conditions}

Clear PVC root tubes measuring $10.2 \mathrm{~cm}$ in diameter and $122 \mathrm{~cm}$ in length, which contained a 7.6- $\mathrm{cm}$ deep gravel base, with three drainage holes at the bottom were used. These tubes were filled with sterilized sand premixed with $17 \mathrm{~N}-2.6 \mathrm{P}-8.3 \mathrm{~K}$ resin-coated fertilizer (Osmocote) to provide $24 \mathrm{~kg}$ nitrogen $(\mathrm{N}) / \mathrm{ha}$. The sand particle size distribution met U.S. Golf Association putting green specifications. Tubes were vibrated manually until a uniform column formed. Each tube was placed in a black PVC sleeve with a bottom cap drilled with holes for drainage. Sod pieces $(10 \mathrm{~cm}$ in diameter) of seashore paspalum (Paspalum vaginatum Swartz) cultivars Salam, Excalibur, and Adalayd were collected from different golf courses in Egypt using a cup cutter. After removing the soil by handwashing, sod pieces were planted into these tubes after roots were trimmed. A total of 162 tubes, arranged in a randomized complete block design with four replications, were then placed in a rack and supported at $15^{\circ}$ angles from the vertical so that root growth could be observed along the side of the tubes. Plants were grown in the greenhouse with the daytime temperature ranging from 25.0 to $30.0{ }^{\circ} \mathrm{C}$, whereas nighttime temperature ranged from 20.0 to $25.0{ }^{\circ} \mathrm{C}$. These temperatures are within optimal ranges for warm-season grasses (Beard, 1982). Photosynthetically active radiation above the canopy at $1000 \mathrm{HR}$ was approximately 1000 $\mu \mathrm{mol} \cdot \mathrm{m}^{-2} \cdot \mathrm{s}^{-1}$. A $20 \mathrm{~N}-10 \mathrm{P}-20 \mathrm{~K}$ soluble fertilizer containing all the micronutrients was applied weekly to each tube throughout the study period resulting in $24 \mathrm{~kg} \mathrm{~N} / \mathrm{ha}$ monthly. Turf in one-third of the tubes was handclipped every $2 \mathrm{~d}$ at $50.0 \mathrm{~mm}$. Turf in the remaining tubes was clipped to the lower mowing height treatments with clipping occurring gradually to avoid scalping before applying treatments.

\section{Treatments}

Water regimes applied included control ( $100 \%$ of the total ET) as well as $75 \%, 50 \%$, and $25 \%$ of the total ET. ET was measured weekly. Two representative tubes for each mowing height of each cultivar were used as lysimeters and were watered with enough water and left to drain for $2 \mathrm{~h}$, after which the weight of each tube was recorded. Each tube was reweighed every $24 \mathrm{~h}$. The daily changes in weight represent the daily ET for each species under the specific mowing height. Water regimes were adjusted weekly according to the changes in the ET. Concurrent to the initiation of the water regimes, mowing treatments were started. Mowing treatments included hand-clipping one time weekly at $45.0 \mathrm{~mm}$, two times weekly at $35.0 \mathrm{~mm}$, and three times weekly at $25.0 \mathrm{~mm}$. Treatments continued for 4 months. The experiment was conducted once in Aug. 2008 and repeated in Aug. 2009.

\section{Measurements}

ET measurements were collected every 2 to $3 \mathrm{~d}$ during the 4 months. Five weight readings per tube were made during each measurement and the average value was used for ET calculation. ET was calculated by mass difference and expressed as $\mathrm{mm} \cdot \mathrm{d}^{-1}$. Visual turf quality was rated biweekly based on color, density, and uniformity using a scale of 0 (brown, dead turf) to 9 (optimum color, density, and uniformity) with a rating of 6.0 or higher indicating acceptable quality. At the end of the experiment, MRE was determined by measuring the length of the deepest root visible at the sand-root tube interface. Root tubes were laid horizontally and cut into four 30-cm-long sections. After washing, a methyl-based violet staining solution was applied to enhance the image of finer roots. RLDs at 0 to 30,30 to 60,60 to 90 , and 90 to $120 \mathrm{~cm}$ were determined with a digital image analyzing system (Delta-T Devices Ltd., Cambridge, U.K.). The system was calibrated daily with pieces of threads of known lengths. Root length density was defined as root length divided by the volume of the soil core. After length measurements, samples were dried in a laboratory oven at $70{ }^{\circ} \mathrm{C}$ for $24 \mathrm{~h}$ and root mass was determined by weigh (mg per tube).

$\mathrm{TNC}$, RSC, and proline content were determined at the termination of the experiment. Aboveground tissues (shoots and stolons) were harvested and washed with cold distilled water to remove plant debris for TNC analysis. Then, $\approx 5 \mathrm{~g}$ of samples were freezedried (Genesis 25 LL Lyophilizer; Virtis, Gardiner, NY). After freeze-drying, samples were ground with a Wiley mill, sieved thought a screen with $425-\mu \mathrm{m}$ openings and kept in airtight vials at $-20{ }^{\circ} \mathrm{C}$. Total nonstructural carbohydrate content was measured using the method described by Chatterton et al. (1987) and explained in detail by Shahba et al. (2012). To measure the free reducing sugar, $25 \mathrm{mg}$ of the freeze-dried, ground, and sieved samples were extracted with $10 \mathrm{~mL} 0.1 \mathrm{M}$ phosphate buffer $(\mathrm{pH}=5.4)$ for $24 \mathrm{~h}$ at room temperature. An extracted aliquot $(0.2 \mathrm{~mL})$ was then used to determine the reducing sugar content by using the same method as was used to measure TNC.

Actual proline tissue accumulation levels were determined according to the method of Bates et al. (1973) as modified by Torello and Rice (1986) with $\approx 0.5 \mathrm{~g}$ fresh weight of tissue and explained in detail by Shahba et al. (2012).

\section{Statistical analysis}

A split-split plot experimental design was used with water regimes being the main plot, mowing heights being the subplots, and cultivars being the sub-subplot factor. Treatments were replicated four times. The data of the two experiments were subjected to analysis of variance (ANOVA) to test the experiment effect and the interaction between treatments and experiments. There was no significant difference between the two experiments. Therefore, data were pooled over experiments to test the effects of drought, mowing height, cultivar, and their interactions using ANOVA (SAS Institute, 2006). Turf quality was analyzed on individual measurement dates to examine drought, mowing, and cultivar effects over time. Because a significant interaction of mowing regime and drought treatments was often observed, comparisons of drought treatments within individual mowing heights are presented with means separated by least significant difference at the 0.05 level of probability. Regression analysis was performed to determine the relationship between the measured parameters 
Table 1. Analysis of variances with mean square and treatment significance of turf quality (TQ, 0-9 scale), evapotranspiration (mm· $\left.\mathrm{d}^{-1}\right)$, total non-structure carbohydrate content (TNC, $\mathrm{mg}^{-\mathrm{g}^{-1}}$ dry wt), shoot reducing sugar content (RSC, $\mathrm{mg}^{-\mathrm{g}^{-1}} \mathrm{dry}$ wt), proline content ( $\mu \mathrm{g} \cdot \mathrm{g}^{-1}$ fresh wt), root length density (RLD, $\left.\mathrm{cm} \cdot \mathrm{cm}^{-3}\right)$, maximum root extension $(\mathrm{MRE}, \mathrm{cm})$, total root length $(\mathrm{cm})$, and root mass $(\mathrm{RM}, \mathrm{mg} / \mathrm{tube})$.

\begin{tabular}{|c|c|c|c|c|c|c|c|c|}
\hline \multirow[b]{2}{*}{ Source } & \multirow[b]{2}{*}{ TQ } & \multirow[b]{2}{*}{ Evapotranspiration } & \multirow[b]{2}{*}{$\mathrm{TNC}$} & \multirow[b]{2}{*}{$\mathrm{RSC}$} & \multirow[b]{2}{*}{ Proline content } & \multicolumn{3}{|c|}{ Rooting characteristics } \\
\hline & & & & & & RLD & MRE & RM \\
\hline Cultivars (C) & $8.4 * *$ & $2.38 * *$ & $6022 * *$ & $23211 * *$ & $21123^{* *}$ & $1.5 * *$ & $18.5 * *$ & $2.9 * *$ \\
\hline Mowing height $(\mathrm{H})$ & $6.7^{*}$ & $3.26 * *$ & $4133 * *$ & $2944 * *$ & $1213 * *$ & $1.1 * *$ & $33.2 * *$ & $3.1 * *$ \\
\hline Drought level (DL) & $55.6 * *$ & $2.55 * *$ & $898 * *$ & $987 * *$ & $1256 * *$ & $1.7 * *$ & $18.8 * *$ & $4.1 * *$ \\
\hline $\mathrm{C} \times \mathrm{H}$ & $5.9^{*}$ & $1.22 *$ & $1225^{*}$ & $1012 *$ & $1109^{*}$ & $1.8 *$ & $9.9 *$ & $2.7 *$ \\
\hline $\mathrm{DL} \times \mathrm{H}$ & $4.8^{*}$ & $3.18 *$ & $724 *$ & $366^{*}$ & $424 *$ & $0.9 *$ & $8.6^{*}$ & $2.2 *$ \\
\hline $\mathrm{DL} \times \mathrm{C}$ & $52.2 *$ & $1.22 *$ & $512 *$ & $36.7 *$ & $75.4 *$ & $2.1 *$ & $8.7^{*}$ & $2.5^{*}$ \\
\hline $\mathrm{C} \times \mathrm{DL} \times \mathrm{H}$ & $0.10 \mathrm{NS}$ & $0.37 \mathrm{NS}$ & $51.0 \mathrm{NS}$ & $25.6 \mathrm{NS}$ & $22.4 \mathrm{NS}$ & $0.1 \mathrm{NS}$ & $4.4 \mathrm{NS}$ & $0.8 \mathrm{NS}$ \\
\hline
\end{tabular}

*Significant at $P=0.05$; **significant at $P=0.01$.

$\mathrm{NS}=$ Nonsignificant.

at the end of the study (dependent variables) and the drought levels (independent variable).

\section{Results and Discussion}

\section{Turf quality}

Turf quality showed significant variations among cultivars, mowing heights, and drought levels (Table 1$)$. Average quality ranged from 8 to $9(0$ to 9 scale with $9=$ the best $)$ at the control treatment with no significant difference among cultivars or mowing heights (Fig. 1). With the increase in drought levels, turf quality declined and significant differences occurred among cultivars and among mowing heights. Turfgrass quality declined more rapidly and severely at lower mowing heights with the increase in drought level. 'Salam' showed greater drought resistance followed by 'Excalibur' and 'Adalayd', which had the lowest drought resistance. 'Salam' turf quality declined only to the unacceptable rating of 5.5 and 4.5 when mowed to 35 and $25 \mathrm{~mm}$, respectively, whereas quality was 6.5 at the mowing height of $45 \mathrm{~mm}$ under the water regime of $25 \%$ of total ET. 'Excalibur' did not show acceptable turf quality at the $25 \%$ treatment, whereas 'Adalayd' did not show such quality at both $50 \%$ and $25 \%$ water regimes under all mowing heights (Fig. 1). Turf quality decreased linearly with the decrease in irrigation water applied under the three mowing heights. Mowing height effect on quality was more obvious at the lowest water regime. Regressions were strongly linear with higher slope at $25.0 \mathrm{~mm}$ than at either 35.0 or $45.0 \mathrm{~mm}$ (Table 2 ).

Jiang and Huang (2001) have examined the adverse effects of drought and heat on tall fescue (Festuca arundinacea L.) and kentucky bluegrass (Poa pratensis L.) turf quality. They reported a decline in turf quality of both tall fescue and kentucky bluegrass and related this to a decrease in water content, not chlorophyll content. Under drought conditions, excessive loss in water content is expected and as a result, rapid cell desiccation, which may lead to a decrease in enzyme activities and an increase in membrane lipid peroxidation (Jiang and Huang, 2001; Nobel, 1988a, 1988b; Turner et al., 1966). Shearman (1986) reported that shoot vertical extension rate was positively correlated with water use rate for 20 kentucky bluegrass cultivars with an upright growth pattern. However, no

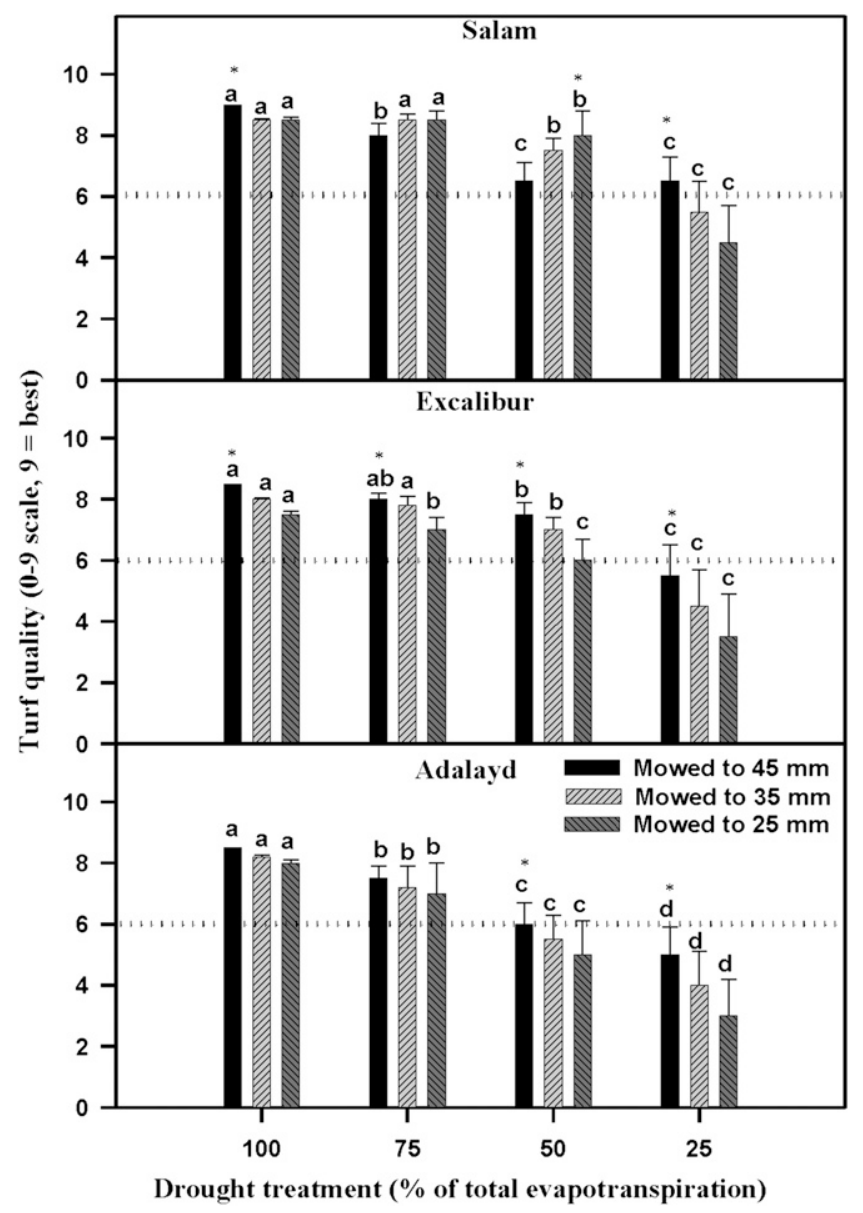

Fig. 1. Effect of different water regimes on seashore paspalum cultivars turf quality at 25-, 35-, and 45-mm mowing heights. Columns labeled with the same letters are not significantly different at $P=0.05$ within the same mowing height. Columns labeled with an asterisk are significantly higher $(P=0.05)$ for mowing height comparison within each drought treatment. Vertical bars at the top of the columns represent SEM. Dotted lines indicate the acceptable quality rating.

correlation was found between water use and leaf extension rate for several warmseason turfgrass species that have a prostate growth habit such as bermudagrass (Beard et al., 1992) and zoysiagrass (Green et al., 1991). In our case, seashore paspalum cultivars showed a positive association between canopy quality and height and water use.

\section{Water use efficiency}

Drought avoidance is an important drought resistance strategy. Drought avoidance can be achieved through the reduction in water use or water loss through the canopy and increasing water uptake of roots from deeper soils. ET is a measure of water use efficiency and is an indicator of turf vigor. ET varied significantly $(P<0.05)$ among cultivars under different water regimes, among mowing heights within cultivars, and among water regimes within cultivars and within mowing heights (Table 1). ET rate declined with the reduction in irrigation water. The decline in ET rate under lower water regimes was more severe and more rapid at lower mowing heights for all cultivars (Fig. 2). 'Salam' 
Table 2. Linear regression of average turf quality, root length density at 0 to $120 \mathrm{~cm}$ depth (RLD), and root mass of paspalum cultivars versus drought levels.

\begin{tabular}{|c|c|c|c|c|c|c|c|}
\hline Cultivars & Mowing ht $(\mathrm{mm})$ & \multicolumn{6}{|c|}{ Parameter } \\
\hline \multirow[t]{2}{*}{ Salam } & 25 & $Y=6.89-0.09 X$ & $0.88^{* *}$ & $Y=1.4-0.19 X$ & $0.83^{* *}$ & $\mathrm{Y}=422.4+11.5 \mathrm{X}$ & $0.66^{*}$ \\
\hline & 45 & $Y=7.66-0.32 X$ & $0.90 * *$ & $\mathrm{Y}=0.6-0.11 \mathrm{X}$ & $0.88^{* *}$ & $\mathrm{Y}=340.5+12.5 \mathrm{X}$ & $0.61 * *$ \\
\hline \multirow[t]{2}{*}{ Excalibur } & 25 & $Y=7.88-0.08 X$ & $0.90 * *$ & $\mathrm{Y}=1.2-0.12 \mathrm{X}$ & $0.91^{* *}$ & $\mathrm{Y}=411.8+12.8 \mathrm{X}$ & $0.56^{*}$ \\
\hline & 35 & $\mathrm{Y}=8.22-0.05 \mathrm{X}$ & $0.92 * *$ & $Y=0.7-0.09 X$ & $0.90 * *$ & $\mathrm{Y}=392.8+11.5 \mathrm{X}$ & $0.62 * *$ \\
\hline \multirow[t]{3}{*}{ Adalayd } & 25 & $\mathrm{Y}=7.22-0.20 \mathrm{X}$ & $0.92 * *$ & $\mathrm{Y}=1.1-0.18 \mathrm{X}$ & $0.88 * *$ & $\mathrm{Y}=380.9+11.9 \mathrm{X}$ & $0.52 *$ \\
\hline & 35 & $\mathrm{Y}=6.75-0.14 \mathrm{X}$ & $0.94^{* *}$ & $\mathrm{Y}=0.8-0.13 \mathrm{X}$ & $0.91 * *$ & $\mathrm{Y}=292.5+10.7 \mathrm{X}$ & $0.58 * *$ \\
\hline & 45 & $\mathrm{Y}=7.11-0.13 \mathrm{X}$ & $0.85^{* *}$ & $\mathrm{Y}=0.4-0.60 \mathrm{X}$ & $0.86^{* *}$ & $\mathrm{Y}=215.7+11.0 \mathrm{X}$ & $0.60 * *$ \\
\hline
\end{tabular}

*Significant at $P=0.05 ; *$ significant at $P=0.01$.

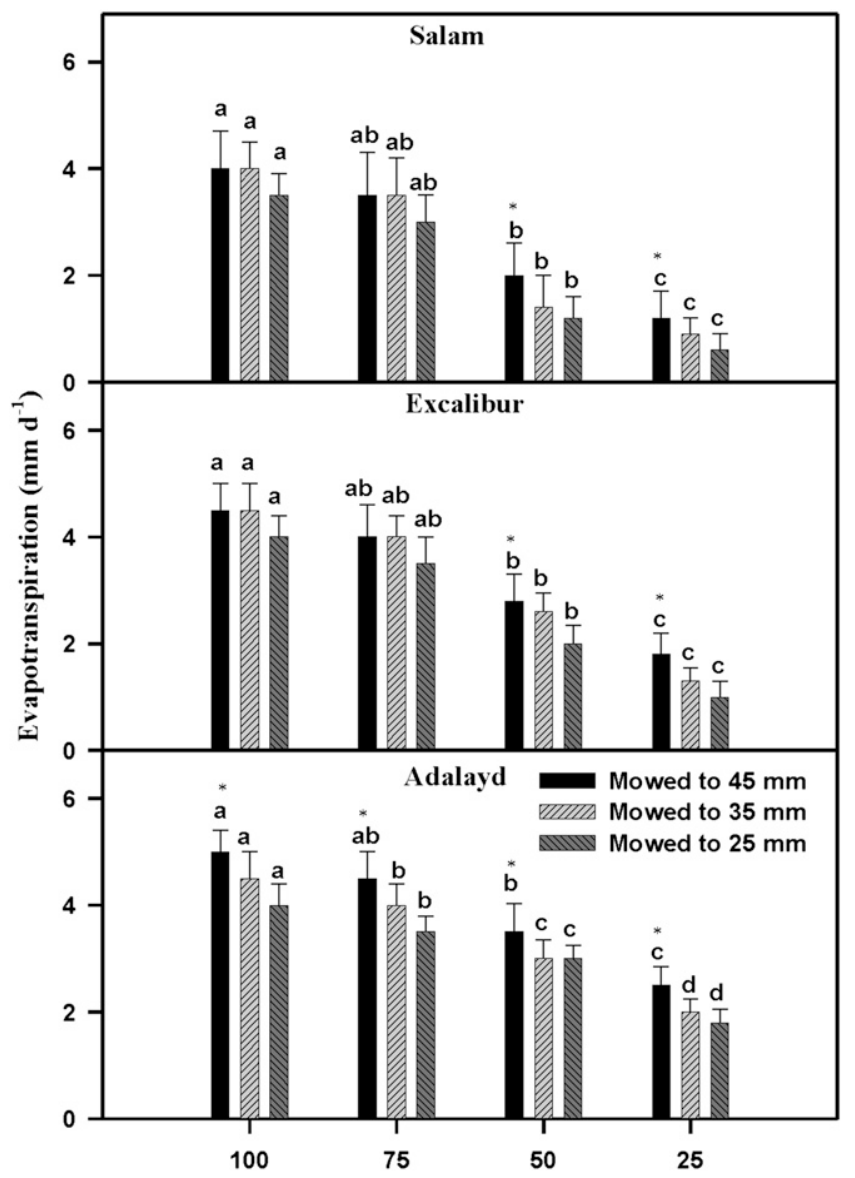

Water regimes (\% of total evapotranspiration)

Fig. 2. Effect of different water regimes on daily evapotranspiration $\left(\mathrm{mm} \cdot \mathrm{d}^{-1}\right)$ of seashore paspalum cultivars at 25-, 35-, and 45-mm mowing heights. Columns labeled with the same letters are not significantly different at $P=0.05$ within the same mowing height. Columns labeled with an asterisk are significantly higher $(P=0.05)$ for mowing heights comparison within each drought treatment. Vertical bars at the top of the columns represent SEM.

showed lower ET rates under all mowing heights and water regimes below $75 \%$ compared with 'Excalibur' and 'Adalayd'. There was no significant difference among cultivars at $100 \%$ and $75 \%$ water regimes. 'Adalayd' had the highest ET rates at the two lower water regimes $(50 \%$ and $25 \%$ of total ET) (Fig. 2).

Transpiration efficiency (TE) has been identified as one of the important physiological traits for improving drought adaptation of crops. The variation in TE is associated with variation in photosynthetic capacity per unit leaf area because thicker leaves usually have a higher density of chlorophyll per unit leaf area and hence have a greater photosynthetic capacity when compared with thinner leaves (Kim and Beard, 1988). 'Salam' had greater TE because it was able to maintain its ET at lower rates while maintaining higher quality turf when compared with 'Excalibur', which was second, whereas 'Adalayd' has the lowest TE. At the 25-mm mowing height, the average daily ET of 'Salam' was $0.6 \mathrm{~mm} \cdot \mathrm{d}^{-1}$ at the lowest water regime $(25 \%$ of the total daily ET), which represents $33.3 \%$ of 'Adalayd' and $60 \%$ of 'Excalibur', which were 1.0 and $1.8 \mathrm{~mm} \cdot \mathrm{d}^{-1}$, respectively. There was no significant difference between both cultivars at the control treatment $(100 \%$ of the total ET).

Seashore paspalum has considerable interspecific diversity for various environmental stresses, including drought (Duncan, 1999; Lee et al., 2004c; Trenholm et al., 1999). Kim and Beard (1988) found that species/cultivar difference in ET rates under non-limiting soil moisture conditions was associated with canopy resistance and total leaf area. High canopy resistance and/or a low leaf area resulted in lower ET. Arunyanark et al. (2008) reported a reduction in transpiration rate as a result of drought, whereas the TE, as indicated by total dry matter production, was increased in Peanut (Arachis hypogaea L.).

\section{Rooting characteristics}

Root length density. RLD varied significantly among cultivars, mowing heights, and water regimes. The interaction among cultivars, water regimes, and mowing heights was not significant, whereas the interaction of water regimes and mowing heights was significant (Table 1). Reduced mowing heights along with increasing drought resulted in decreased RLD in seashore paspalum cultivars (Table 3). The decrease in RLD was higher at lower soil depth than in the top $60 \mathrm{~cm}$. In 'Salam', as drought levels increased from control to $25 \%$, average RLD decreased by $76 \%, 75 \%$, and $76 \%$ at $25-, 35-$, and $45-\mathrm{mm}$ mowing heights, respectively, at the top $30 \mathrm{~cm}$ of soil in the column. The change was $93 \%, 85 \%$, and $83 \%$ at $25-, 35-$, and $45-\mathrm{mm}$ mowing heights, respectively, at the deeper soil $(90$ to $120 \mathrm{~cm})$. Similar trends of change were recorded in 'Excalibur' and 'Adalayd'. Rankings of RLD of cultivars was 'Salam' > 'Excalibur' > 'Adalayd' consistently at all mowing heights and at all soil depths (Table 3 ). Greatest RLD was observed within the 0 to $30 \mathrm{~cm}$ in all cultivars. Regression analysis indicated a significant negative association between RLD and drought levels at all mowing heights and soil depths (Table 2). 
Table 3. Root length density $\left(\mathrm{cm} \cdot \mathrm{cm}^{-3}\right)$ at four depths $(0-30,30-60,60-90$, and $90-120 \mathrm{~cm})$ of paspalum cultivars at three mowing heights and four drought treatments.

\begin{tabular}{|c|c|c|c|c|c|c|c|c|c|c|c|c|c|c|c|c|c|}
\hline \multirow[b]{3}{*}{ Cultivars } & \multirow{3}{*}{$\begin{array}{l}\text { Mowing } \\
\text { ht }(\mathrm{mm})\end{array}$} & \multicolumn{16}{|c|}{ Drought level (percent of total evapotranspiration) } \\
\hline & & \multicolumn{4}{|c|}{$100 \%$} & \multicolumn{4}{|c|}{$75 \%$} & \multicolumn{4}{|c|}{$50 \%$} & \multicolumn{4}{|c|}{$25 \%$} \\
\hline & & $0-30$ & $30-60$ & $60-90$ & $90-120$ & $0-30$ & $30-60$ & $60-90$ & $90-120$ & $0-30$ & $30-60$ & $60-90$ & $90-120$ & $0-30$ & $30-60$ & $60-90$ & $90-120$ \\
\hline \multirow[t]{3}{*}{ Salam } & 25 & $2.9 c^{z}$ & $2.0 \mathrm{c}$ & $0.8 \mathrm{~b}$ & $0.3 \mathrm{~b}$ & $2.1 \mathrm{c}$ & $1.5 \mathrm{~b}$ & $0.6 \mathrm{~b}$ & 0.1 & $1.4 \mathrm{~b}$ & $1.0 \mathrm{c}$ & $0.4 \mathrm{~b}$ & 0.08 & 0.7 & $0.5 \mathrm{~b}$ & 0.1 & $0.02 \mathrm{c}$ \\
\hline & 35 & $3.2 \mathrm{~b}$ & $2.3 \mathrm{bc}$ & $1.0 \mathrm{~b}$ & $0.4 \mathrm{ab}$ & $2.5 \mathrm{~b}$ & $1.7 \mathrm{~b}$ & $0.8 \mathrm{a}$ & 0.2 & $1.6 \mathrm{~b}$ & $2.3 \mathrm{~b}$ & $0.5 \mathrm{~b}$ & 0.2 & 0.8 & $1.1 \mathrm{a}$ & 0.2 & $0.06 \mathrm{~b}$ \\
\hline & 45 & $3.9 \mathrm{a}$ & $2.9 \mathrm{a}$ & $1.6 \mathrm{a}$ & $0.6 \mathrm{a}$ & $2.9 \mathrm{a}$ & $2.1 \mathrm{a}$ & $1.0 \mathrm{a}$ & 0.3 & $1.9 \mathrm{a}$ & $2.9 \mathrm{a}$ & $0.8 \mathrm{a}$ & 0.3 & 0.9 & $1.4 \mathrm{a}$ & 0.3 & $0.1 \mathrm{a}$ \\
\hline \multirow[t]{3}{*}{ Excalibur } & 25 & $2.2 \mathrm{c}$ & $1.3 \mathrm{~b}$ & $0.6 \mathrm{~b}$ & 0.2 & $1.6 \mathrm{c}$ & $0.9 \mathrm{~b}$ & $0.4 \mathrm{~b}$ & 0.1 & $1.1 \mathrm{c}$ & $1.3 \mathrm{~b}$ & 0.3 & 0.1 & 0.5 & $0.6 \mathrm{~b}$ & 0.1 & $0.01 \mathrm{c}$ \\
\hline & 35 & $2.9 \mathrm{~b}$ & $1.9 \mathrm{a}$ & $0.9 \mathrm{a}$ & 0.3 & $2.1 \mathrm{ab}$ & $1.4 \mathrm{a}$ & $0.6 \mathrm{a}$ & 0.1 & $1.4 \mathrm{~b}$ & $1.9 \mathrm{a}$ & 0.4 & 0.15 & 0.7 & $0.9 \mathrm{a}$ & 0.2 & $0.05 \mathrm{a}$ \\
\hline & 45 & $3.2 \mathrm{a}$ & $2.1 \mathrm{a}$ & $1.0 \mathrm{a}$ & 0.4 & $2.4 \mathrm{a}$ & $1.5 \mathrm{a}$ & $0.7 \mathrm{a}$ & 0.1 & $1.7 \mathrm{a}$ & $2.1 \mathrm{a}$ & 0.5 & 0.2 & 0.8 & $1.0 \mathrm{a}$ & 0.3 & $0.08 \mathrm{a}$ \\
\hline \multirow[t]{3}{*}{ Adalayd } & 25 & $1.8 \mathrm{c}$ & $0.9 \mathrm{~b}$ & 0.4 & 0.1 & $1.4 \mathrm{c}$ & $0.6 \mathrm{~b}$ & $0.3 \mathrm{~b}$ & 0.05 & $0.8 \mathrm{c}$ & $0.9 \mathrm{~b}$ & 0.2 & 0.05 & 0.4 & 0.4 & 0.1 & $0.01 \mathrm{~b}$ \\
\hline & 35 & $2.2 \mathrm{~b}$ & $1.1 \mathrm{ab}$ & 0.6 & 0.2 & $1.6 \mathrm{~b}$ & $0.8 \mathrm{a}$ & $0.4 \mathrm{a}$ & 0.1 & $1.1 \mathrm{ab}$ & $1.1 \mathrm{~b}$ & 0.3 & 0.1 & 0.5 & 0.5 & 0.1 & $0.04 \mathrm{a}$ \\
\hline & 45 & $2.6 \mathrm{a}$ & $1.4 \mathrm{a}$ & 0.8 & 0.3 & $1.9 \mathrm{a}$ & $1.0 \mathrm{a}$ & $0.6 \mathrm{a}$ & 0.1 & $1.3 \mathrm{a}$ & $1.4 \mathrm{a}$ & 0.4 & 0.15 & 0.6 & 0.7 & 0.2 & $0.05 \mathrm{a}$ \\
\hline
\end{tabular}

${ }^{z}$ Values followed by the same letters within a column for each cultivar are not significantly different $(P=0.05)$ based on a Fisher's least significant difference test.

Maximum root extension. MRE varied significantly among cultivars, mowing heights, and water regimes. The interactions among cultivars, water regimes, and mowing heights were not significant, whereas that of water regimes and mowing heights was significant (Table 1). Increasing drought levels and reducing mowing height decreased MRE. As drought gradually increased from control to $75 \%$ and $50 \%$, MRE increased at all mowing heights. A farther increase in drought to $25 \%$ inversely affected MRE (Fig. 3). 'Salam' achieved the highest MRE at all mowing heights under all water regimes followed by 'Excalibur' and 'Adalayd'. Higher mowing heights resulted in greater root extension. When water is not limited at the control treatments, root extension was less than when water was reduced to $75 \%$ or $50 \%$, but when reduced to $25 \%$, root growth was negatively affected (Fig. 3). In 'Salam', on average overall water regimes, MRE at $45 \mathrm{~mm}$ was $\approx 10 \%$ to $17 \%$ greater than that of $35-\mathrm{mm}$ mowing height and $28 \%$ to $36 \%$ greater than that of $25-\mathrm{mm}$ mowing height. Similar trends were obtained in 'Excalibur' and 'Adalayd'. Rankings of cultivar MRE was 'Salam' > 'Excalibur' > 'Adalayd' consistently at all mowing heights and at all water regimes (Fig. 3).

Total root mass. Total root mass followed the same trend as MRE because seashore paspalum cultivars responded to moderate drought stress by increasing root mass and extension, and when water was not limiting or severely limiting, root growth and extension were adversely affected. Generally, there was a significant increase in root mass as drought increased from $100 \%$ to $75 \%$ and $50 \%$ of the total ET. There was no significant difference $(P<0.05)$ in root mass among cultivars within the same mowing height in the control treatment. However, as drought increased, there were significant differences in root mass among cultivars within the same mowing heights (Table 1). 'Salam' had higher root mass at all water regimes, except for the control treatment followed by 'Excalibur' and 'Adalayd'. Regression analysis indicated a significant positive association between root mass and drought levels at all mowing heights (Table 2). At 45-mm mowing height, 'Salam' root mass increased by

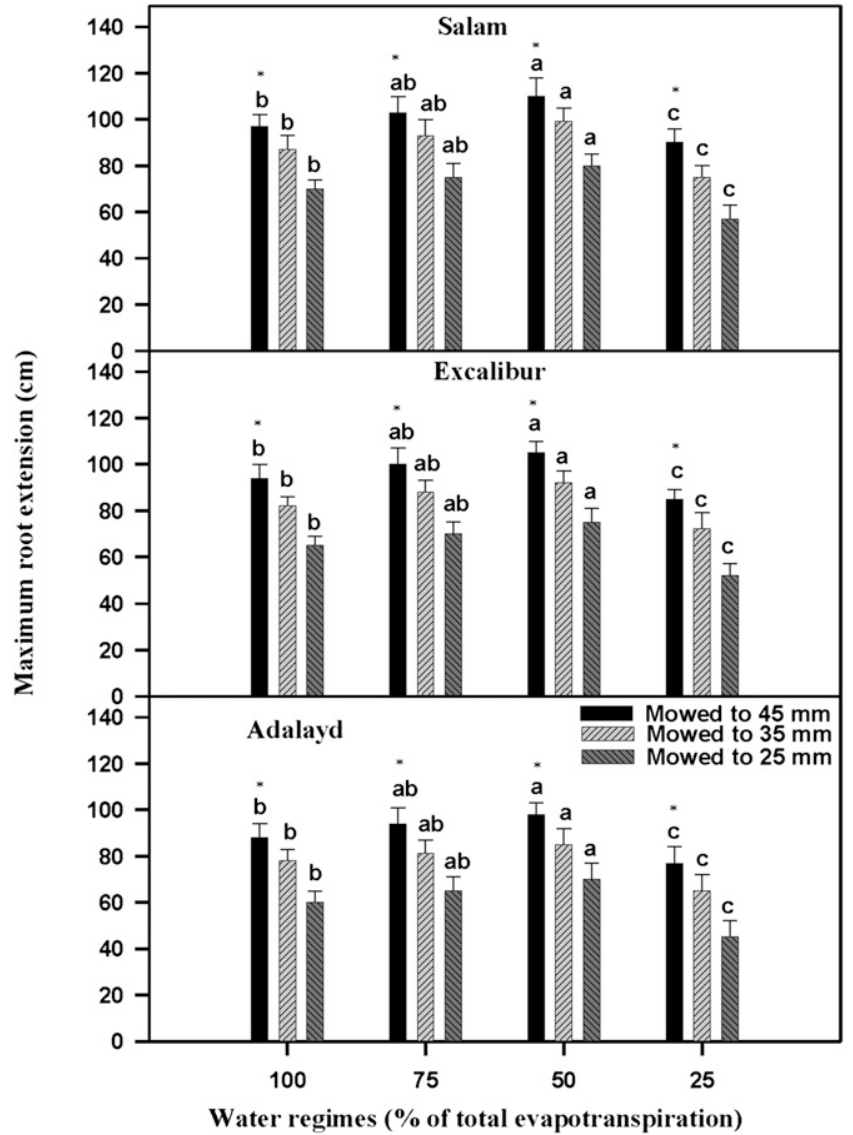

Fig. 3. Effect of different water regimes on maximum root extension $(\mathrm{cm})$ of seashore paspalum cultivars at 25-, 35-, and 45-mm mowing heights. Columns labeled with the same letters are not significantly different at $P=0.05$ within the same mowing height. Columns labeled with an asterisk are significantly higher $(P=0.05)$ for mowing heights comparison within each drought treatment. Vertical bars at the top of columns represent SEM. Dotted lines indicate the suggested threshold $\mathrm{K}^{+} / \mathrm{Na}^{+}$ratio for normal growth.

$61 \%, 93 \%$, and $31 \%$ when drought levels increased from control to $75 \%, 50 \%$, and $25 \%$, respectively. At $35 \mathrm{~mm}$, the change was $68 \%, 97 \%$, and $30 \%$, whereas the change was $72 \%, 100 \%$, and $31 \%$ at $25-\mathrm{mm}$ mowing height when drought levels increased from control to $75 \%, 50 \%$, and $25 \%$, respectively.

The highest root mass $(810 \mathrm{mg})$ was obtained when 'Salam' was mowed to $45 \mathrm{~mm}$ and subjected to the drought level of $50 \%$ of the total ET. The lowest root mass $(320 \mathrm{mg})$ was obtained when 'Salam' was mowed to $25 \mathrm{~mm}$ and the water regime was not limiting. At 45-mm mowing height, 'Excalibur' root mass increased by $56 \%, 85 \%$, and $28 \%$ when drought levels increased from control to $75 \%$, $50 \%$, and $25 \%$, respectively. At $35 \mathrm{~mm}$, the change was $54 \%, 74 \%$, and $34 \%$, whereas the change was $53 \%, 120 \%$, and $32 \%$ at $25-\mathrm{mm}$ mowing height when drought levels increased from control to $75 \%, 50 \%$, and $25 \%$, respectively. At 45-mm mowing height, 'Adalayd' 
root mass increased by $42 \%, 72 \%$, and $17 \%$ when drought levels increased from control to $75 \%, 50 \%$, and $25 \%$, respectively. At $35 \mathrm{~mm}$, the change was $54 \%, 93 \%$, and $25 \%$, whereas the change was $72 \%, 123 \%$, and $4.6 \%$ at 25-mm mowing height when drought levels increased from control to $75 \%, 50 \%$, and $25 \%$, respectively. The change was minimal $(4.6 \%)$ in 'Adalayd' at 25-mm mowing height under the water regime of $25 \%$ of the total ET (Fig. 4).

Similar to our results, several reports $(\mathrm{Fu}$ et al., 2005; Krans and Beard, 1975; Salaiz et al., 1995; Shahba, 2010b; Shahba et al., 2012) indicated that mowing height significantly affects the total root mass of different turfgrasses including seashore paspalum cultivars. Kramer (1980) indicated that deep and extensive root system is one of the most important mechanisms adopted by turfgrasses to increase water absorption and thus avoid drought stress. Obviously, RLD, total root length, and total root mass (TRM) data are similar to previous reports that demonstrated a positive correlation between root production and dehydration avoidance (Suplick-Ploense and Qian, 2005). Hays et al. (1991) reported that bermudagrass root mass at different depths $(30$ to $150 \mathrm{~cm}$ ) was correlated with turf quality during drought in a greenhouse study. Kopec (1985) reported similar observations in tall fescue clones in a field study. Several reports indicated the increase in root mass under stress conditions in several grasses at mowing heights ranging from 35 to 75 mm (Dudeck et al., 1983; Fu et al. 2005; Peacock and Dudeck, 1985; Shahba et al., 2012). However, Keeley and Koski (2001) considered root distribution as more important factor than total root mass in drought avoidance in kentucky bluegrass.

Higher root mass in 'Salam' may explain its greater drought resistance when compared with 'Excalibur' and 'Adalayd'. Seashore paspalum cultivars' root growth indicates rooting efficiency but not activity. Relative activity of the roots may be evaluated in this study by TE, although more information is needed to assess root activity in turfgrasses.

\section{Osmotic adjustment}

Osmotic adjustment facilitates water uptake and limits water loss from cells. Thus, tissues may sustain metabolic and physiological functions under drought stress in addition to the stability of cell membrane. Tested osmotic adjustment parameters included shoot total nonstructural carbohydrates, total reducing sugar content, and shoot proline content.

Shoot total nonstructural carbohydrates and total reducing sugar content. Shoot TNC varied significantly among cultivars, mowing heights, and water regimes. Also, the interaction of water regimes and mowing treatments was significant. The interaction of all three parameters, i.e., among cultivars, water regimes, and mowing heights, was not significant (Table 1). Increasing drought and reducing mowing height decreased shoot TNC of paspalum cultivars (Table 4). In

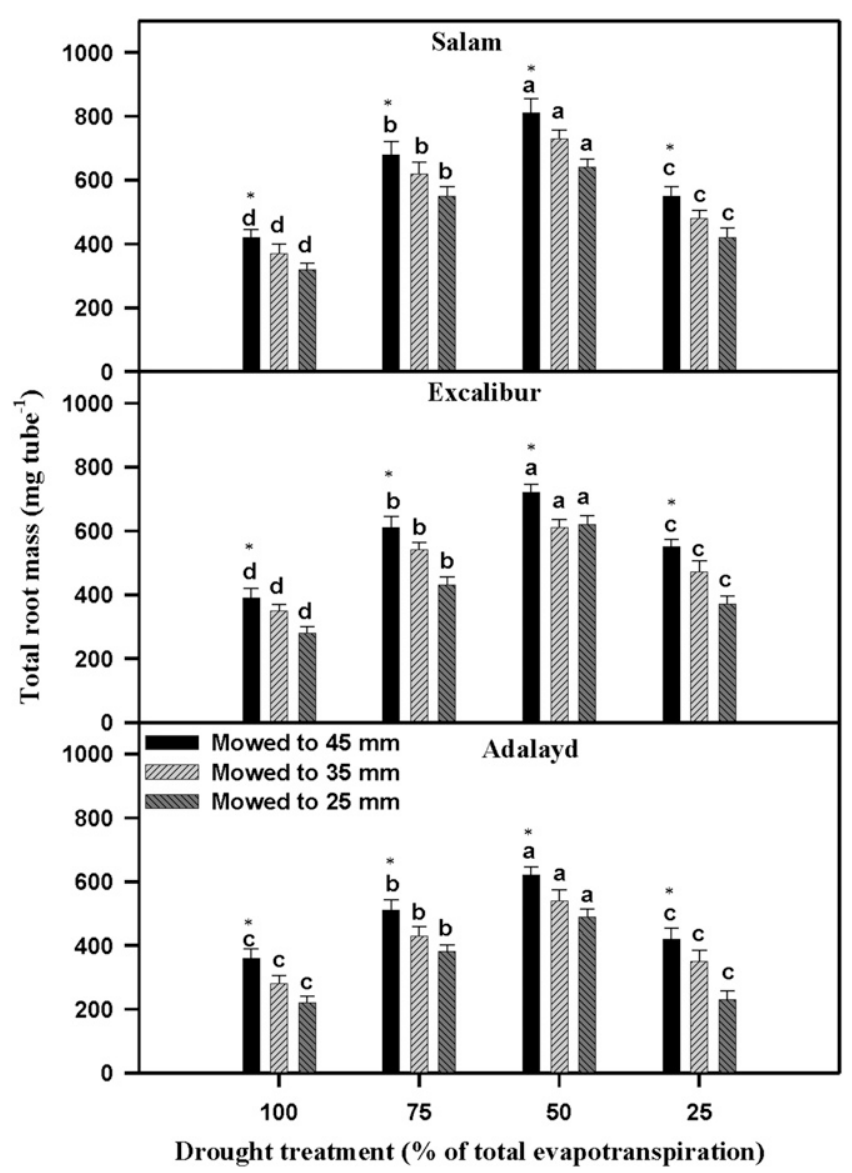

Fig. 4. Effect of different water regimes on total root mass of paspalum cultivars at 25-, 35-, and 45-mm mowing heights. Columns labeled with the same letters are not significantly different at $P=0.05$ within the same mowing height. Columns labeled with an asterisk are significantly higher $(P=0.05)$ for mowing heights comparison within each drought treatment. Vertical bars at the top of the columns represent SEM.

Table 4. Total nonstructural carbohydrates (TNC) in shoots of seashore paspalum cultivars subjected to three mowing heights and four drought treatments. ${ }^{\mathrm{z}}$

\begin{tabular}{|c|c|c|c|c|c|c|c|}
\hline \multirow[b]{3}{*}{ Cultivars } & \multirow{3}{*}{$\begin{array}{l}\text { Mowing } \\
\text { ht }(\mathrm{mm})\end{array}$} & \multicolumn{4}{|c|}{ TNC (mg.g ${ }^{-1}$ dry wt) } & \multirow[b]{3}{*}{ Regression } & \multirow[b]{3}{*}{$\mathrm{R}^{2}$} \\
\hline & & \multicolumn{4}{|c|}{ Drought level (percent of total evapotranspiration) } & & \\
\hline & & $100 \%$ & $75 \%$ & $50 \%$ & $25 \%$ & & \\
\hline \multirow[t]{3}{*}{ Salam } & 25 & $124.2 \mathrm{c}^{\mathrm{y}}$ & $99.2 \mathrm{~b}$ & $79.8 \mathrm{c}$ & $70.1 \mathrm{~b}$ & $\mathrm{Y}=121.5-1.1 \mathrm{X}$ & $0.90 * *$ \\
\hline & 35 & $134.7 \mathrm{~b}$ & $115.2 \mathrm{a}$ & $119.6 \mathrm{~b}$ & $99.2 \mathrm{a}$ & $Y=135.1-1.2 \mathrm{X}$ & $0.72 *$ \\
\hline & 45 & $149.2 \mathrm{a}$ & $122.1 \mathrm{a}$ & $125.1 \mathrm{a}$ & $112.1 \mathrm{a}$ & $Y=145.2-1.4 \mathrm{X}$ & $0.76^{*}$ \\
\hline \multirow[t]{3}{*}{ Excalibur } & 25 & $113.2 \mathrm{c}$ & $88.8 \mathrm{~b}$ & $73.2 \mathrm{~b}$ & $59.2 \mathrm{~b}$ & $Y=119.5-0.9 X$ & $0.94 * *$ \\
\hline & 35 & $122.6 \mathrm{~b}$ & $103.1 \mathrm{a}$ & $94.6 \mathrm{a}$ & $86.1 \mathrm{a}$ & $\mathrm{Y}=128.2-1.2 \mathrm{X}$ & $0.70 *$ \\
\hline & 45 & $135.2 \mathrm{a}$ & $108.9 \mathrm{a}$ & $97.5 \mathrm{a}$ & $92.6 \mathrm{a}$ & $Y=137.8-0.8 X$ & $0.85 * *$ \\
\hline \multirow[t]{3}{*}{ Adalayd } & 25 & $111.2 \mathrm{c}$ & $75.2 \mathrm{~b}$ & $65.8 \mathrm{c}$ & $54.2 \mathrm{c}$ & $Y=116.1-0.8 X$ & $0.94 * *$ \\
\hline & 35 & $120.2 \mathrm{~b}$ & $79.5 \mathrm{~b}$ & $82.9 \mathrm{~b}$ & $69.4 \mathrm{~b}$ & $\mathrm{Y}=122.5-1.1 \mathrm{X}$ & $0.85 * *$ \\
\hline & 45 & $133.2 \mathrm{a}$ & $104.2 \mathrm{a}$ & $94.2 \mathrm{a}$ & $86.1 \mathrm{a}$ & $Y=135.5-0.7 X$ & $0.80 * *$ \\
\hline
\end{tabular}

${ }^{\mathrm{z}}$ Linear egression of TNC of paspalum cultivars versus drought levels at different mowing heights.

${ }^{y}$ Values followed by the same letters within a column for each cultivar are not significantly different $(P=0.05)$ based on a Fisher's least significant difference test.

* Significant at $P=0.05 ; * *$ significant at $P=0.01$.

'Salam', as drought increased from control to $25 \%$ of the total ET, average TNC decreased by $43.5 \%, 26.0 \%$, and $29.0 \%$ and the average TNC decrease in 'Excalibur' shoots was $48.0 \%, 30.0 \%$, and $32.0 \%$, whereas the decrease in 'Adalayd' was $51.3 \%, 42.3 \%$, and $35.4 \%$ at $25-$, 35-, and $45-\mathrm{mm}$ mowing heights, respectively. In general, a decline in
TNC with mowing height reduction is expected, most likely as a result of continued defoliation that removed photosynthetic tissues. High drought enhances stomatal closure and as a result reduces $\mathrm{CO}_{2}$ uptake, which escalated the reduction in TNC. In the control treatment, mowing 'Salam' at $25 \mathrm{~mm}$ reduced TNC by $9.7 \%$ and $16.7 \%$ in comparison with 
that mowed at 35 and $45 \mathrm{~mm}$, respectively. As drought level increased to $25 \%$ of the total ET, the mowing height effect on TNC intensified with TNC reduced by $11.5 \%$ and $37.5 \%$ at 25-mm mowing height in comparison with those mowed at 35 and $45 \mathrm{~mm}$. Regression analysis indicated a significant negative association between water regimes and TNC content in all cultivars at all mowing heights (Table 4).

Shoot RSC varied significantly among cultivars, mowing heights, and water regimes. Also, the interaction of water regimes and mowing treatments on RSC was significant. The interaction among cultivars, water regimes, and mowing heights was not significant relative to RSC (Table 1). It is well known that reducing sugars are the main source of energy that plants use to cope with stress. RSC responded differently to different mowing heights and water regimes compared with TNC (Table 5). Regression analysis indicated a significant positive association between water regimes and RSC content in all cultivars at all mowing heights (Table 5). As drought levels increased from control to $25 \%$ of the total ET, average RSC increased by $57.3 \%, 57.1 \%$, and $53.0 \%$ in 'Salam' and by $59.4 \%, 57.0 \%$, and $51.5 \%$ in 'Excalibur' and $61.2 \%, 58.1 \%$, and $61.0 \%$ in 'Adalayd' at 25-, 35-, and 45-mm mowing height, respectively. Comparing RSC among mowing heights within each water regime indicated a decline in RSC with mowing height reduction. Reducing sugars in grass species mainly consists of glucose and fructose (Shahba et al., 2003). Whereas nonstructural carbohydrates are energy reserves in grasses, soluble reducing sugars are thought to play an important role in salinity, drought, and freezing tolerance as osmoregulators and as protectants because they prevent cell desiccation (Popp and Smirnoff, 1995). Carbon reduction could be related to the drought resistance mechanisms that are energy-dependent. The results suggested that carbohydrate availability was a limiting factor for shoot growth under high drought stress and close mowing height.

Total nonstructural carbohydrates serve as the resource for the increased RSC under drought conditions. The balance between carbohydrate production and consumption will impact the ability of turfgrass species to cope with stresses (Huang and Fry, 1999; Lee et al., 2008a, 2008b; Shahba, 2010b; Shahba et al., 2012).

Shoot proline content. There was no significant difference in proline content among cultivars or among mowing heights. At all water regimes, shoot proline content varied significantly among cultivars and mowing heights. The interaction among cultivars, water regimes, and mowing heights on proline content was not significant (Table 1). Increasing drought increased shoot proline content of seashore paspalum cultivars. The increase in proline content was more intense with increasing mowing heights (Table 6). As drought increased to $25 \%$ of the total ET, average proline content in shoots increased by $435 \%, 432 \%$, and $431 \%$ in 'Salam';

Table 5. Total reducing sugar content (RSC) in shoots of seashore paspalum cultivars subjected to three mowing heights and four drought treatments. ${ }^{\mathrm{z}}$

\begin{tabular}{|c|c|c|c|c|c|c|c|}
\hline \multirow[b]{3}{*}{ Cultivars } & \multirow{3}{*}{$\begin{array}{l}\text { Mowing } \\
\text { ht (mm) }\end{array}$} & \multicolumn{4}{|c|}{ RSC (mg.g ${ }^{-1}$ dry wt) } & \multirow[b]{3}{*}{ Regression } & \multirow[b]{3}{*}{$R^{2}$} \\
\hline & & \multicolumn{4}{|c|}{ Drought level (\% of total evapotranspiration) } & & \\
\hline & & $100 \%$ & $75 \%$ & $50 \%$ & $25 \%$ & & \\
\hline \multirow[t]{3}{*}{ Salam } & 25 & $21.6 \mathrm{c}^{\mathrm{y}}$ & $42.7 \mathrm{~b}$ & $45.3 \mathrm{~b}$ & $50.6 \mathrm{c}$ & $\mathrm{Y}=24.1+0.27 \mathrm{X}$ & $0.72 *$ \\
\hline & 35 & $24.4 \mathrm{~b}$ & $45.5 \mathrm{a}$ & $50.1 \mathrm{a}$ & $56.9 \mathrm{~b}$ & $Y=23.2+0.24 X$ & $0.87 * *$ \\
\hline & 45 & $28.6 \mathrm{a}$ & $49.6 \mathrm{a}$ & $54.6 \mathrm{a}$ & $60.8 \mathrm{a}$ & $\mathrm{Y}=28.2+0.28 \mathrm{X}$ & $0.67^{*}$ \\
\hline \multirow[t]{3}{*}{ Excalibur } & 25 & $18.9 \mathrm{c}$ & $36.5 \mathrm{~b}$ & $42.2 \mathrm{~b}$ & $46.6 \mathrm{c}$ & $Y=21.1+0.32 X$ & $0.69^{*}$ \\
\hline & 35 & $22.2 \mathrm{~b}$ & $42.4 \mathrm{a}$ & $48.1 \mathrm{a}$ & $51.6 \mathrm{~b}$ & $\mathrm{Y}=22.2+0.35 \mathrm{X}$ & $0.86 * *$ \\
\hline & 45 & $27.5 \mathrm{a}$ & $45.2 \mathrm{a}$ & $50.2 \mathrm{a}$ & 56.7 a & $Y=26.8+0.27 X$ & $0.62 *$ \\
\hline \multirow[t]{3}{*}{ Adalayd } & 25 & $15.7 \mathrm{~b}$ & $35.2 \mathrm{~b}$ & $38.4 \mathrm{~b}$ & $40.8 \mathrm{c}$ & $Y=16.9+0.23 X$ & $0.62 *$ \\
\hline & 35 & $19.2 \mathrm{a}$ & $38.4 \mathrm{a}$ & $43.3 \mathrm{a}$ & $45.8 \mathrm{~b}$ & $\mathrm{Y}=14.9+0.22 \mathrm{X}$ & $0.85^{* *}$ \\
\hline & 45 & $20.2 \mathrm{a}$ & $40.7 \mathrm{a}$ & $45.2 \mathrm{a}$ & $51.9 \mathrm{a}$ & $\mathrm{Y}=18.1+0.21 \mathrm{X}$ & $0.71 *$ \\
\hline
\end{tabular}

${ }^{2}$ Linear egression of RSC of paspalum cultivars versus drought levels at different mowing heights.

${ }^{y}$ Values followed by the same letters within a column for each cultivar are not significantly different $(P=0.05)$ based on a Fisher's least significant difference test.

*Significant at $P=0.05 ; *$ significant at $P=0.01$.

Table 6. Proline content in shoots of seashore paspalum cultivars subjected to three mowing heights and four drought treatments. ${ }^{z}$

\begin{tabular}{|c|c|c|c|c|c|c|c|}
\hline \multirow[b]{3}{*}{ Cultivars } & \multirow{3}{*}{$\begin{array}{l}\text { Mowing } \\
\text { ht (mm) }\end{array}$} & \multicolumn{4}{|c|}{ Proline content $\left(\mu \mathrm{g} \cdot \mathrm{g}^{-1}\right.$ fresh wt) } & \multirow[b]{3}{*}{ Regression } & \multirow[b]{3}{*}{$R^{2}$} \\
\hline & & \multicolumn{4}{|c|}{ Drought level (percent of total evapotranspiration) } & & \\
\hline & & $100 \%$ & $75 \%$ & $50 \%$ & $25 \%$ & & \\
\hline \multirow{3}{*}{ Salam } & 25 & 321.8 & $866.9 \mathrm{~b}^{\mathrm{y}}$ & $1266.0 \mathrm{~b}$ & $1720.0 \mathrm{c}$ & $\mathrm{Y}=288.9+22.2 \mathrm{X}$ & $0.87 *$ \\
\hline & 35 & 325.6 & 989.9 a & $1355.0 \mathrm{a}$ & $1729.0 \mathrm{~b}$ & $Y=322.8+26.7 X$ & $0.85 *$ \\
\hline & 45 & 342.3 & $1090.8 \mathrm{a}$ & $1477.0 \mathrm{a}$ & $1820.0 \mathrm{a}$ & $\mathrm{Y}=381.9+31.1 \mathrm{X}$ & $0.82 *$ \\
\hline \multirow[t]{3}{*}{ Exacalibur } & 25 & 301.6 & $666.8 \mathrm{~b}$ & $990.0 \mathrm{~b}$ & $1522.0 \mathrm{c}$ & $\mathrm{Y}=226$ & $0.87 *$ \\
\hline & 35 & 321.9 & 740.9 a & $1020.0 \mathrm{a}$ & $1533.0 \mathrm{~b}$ & $Y=227.9+21.5 X$ & $0.88^{*}$ \\
\hline & 45 & 382.6 & $798.8 \mathrm{a}$ & $1130.0 \mathrm{a}$ & $1622.0 \mathrm{a}$ & $Y=292.6+25.5 X$ & $0.91 *$ \\
\hline \multirow{3}{*}{ Adalayd } & 25 & 288.5 & $466.5 \mathrm{~b}$ & $692.0 \mathrm{~b}$ & $1030.0 \mathrm{c}$ & $Y=218.2+$ & $0.90 *$ \\
\hline & 35 & 295.2 & $555.9 \mathrm{a}$ & $723.0 \mathrm{a}$ & $1115.0 \mathrm{~b}$ & $\mathrm{Y}=227.9+18.6 \mathrm{X}$ & $0.87 *$ \\
\hline & 45 & 299.1 & $579.8 \mathrm{a}$ & $823.0 \mathrm{a}$ & $1202.0 \mathrm{a}$ & $\mathrm{Y}=232.0+18.8 \mathrm{X}$ & $0.89 *$ \\
\hline
\end{tabular}

${ }^{2}$ Linear egression of proline content of paspalum cultivars versus drought levels at different mowing heights.

${ }^{y}$ Values followed by the same letters within a column for each cultivar are not significantly different $(P=0.05)$ based on a Fisher's least significant difference test.

*Significant at $P=0.01$.

$404 \%, 376 \%$, and $324 \%$ in 'Excalibur'; and $257 \%, 278 \%$ and $302 \%$ in 'Adalayd' at $25-$, $35-$, and 45-mm mowing heights, respectively. Comparing proline content among mowing heights within each water regime indicated an increase in proline content as mowing height increased from 25 to $35 \mathrm{~mm}$ except for the control treatment. As drought increased to $25 \%$ of the total ET, the mowing height effect on proline content increased. It was increased by $5.4 \%, 6.2 \%$, and $14.3 \%$ at 45-mm mowing height as compared with those mowed at $25 \mathrm{~mm}$ in 'Salam', 'Excalibur', and 'Adalayd', respectively. Regression analysis indicated a significant positive association between water regimes and proline content in all cultivars at all mowing heights (Table 6). Proline accumulation is the first response of plants exposed to water deficit stress to reduce injury to cells (Ashraf and Foolad, 2007). Our results agree with the previous published work on the positive role for proline in seashore paspalum cultivars' drought tolerance. Rapid accumulation of proline in tissues of many plant species in response to drought, salt, or temperature stresses has been attributed to enzyme stabilization and/or osmoregulation (Flowers et al., 1977; Levitt, 1980). Proline could enhance membrane stability and act as a sink for carbon and $\mathrm{N}$ for stress recovery (Ashraf and Foolad, 2007).

Turfgrass species and cultivars vary in drought resistance. However, little is known of metabolic factors controlling root survival in drying soils and the proteins or genes associated with the accumulation of osmolytes (Huang, 2008). The accumulation of solutes in leaves such as soluble sugars, inorganic ions, and proline has been associated with osmotic adjustment and increased drought tolerance in kentucky bluegrass (Jiang and Huang, 2001), tall fescue (Richardson et al., 1992), perennial ryegrass (Thomas, 1990), and zoysiagrass (Qian et al., 1997). Osmotic adjustment has also been observed in roots of crops, contributing to maintenance of root turgor and elongation in dry soils (Sharp et al., 1990). The capacity for osmotic adjustment in roots in relation to drought tolerance has not been well studied in turfgrass species. A positive correlation between 
the capacity of osmotic adjustment and recovery from prolonged drought has been reported in several turfgrass species, where species with the greatest osmotic adjustment regrew faster after watering (DaCosta and Huang, 2006). Any culture practices that promote accumulation of osmotic solutes during drought stress should be helpful in turfgrass for rapid recovery from that stress. On the basis of the number of times in the best statistical category for turf quality, ET, RLD, MRE, TRE, TNC, RSC, and proline content, the cultivar 'Salam' was found to have the greatest drought resistance when compared with 'Excalibur' and 'Adalayd'. Also, increasing drought levels had less adverse effects on overall responses of all cultivars at higher mowing heights. Whereas the three drought resistance strategies (drought escape, drought avoidance, and drought tolerance) are not mutually exclusive, and the tested cultivars showed more than one strategy to cope with drought stress, the duration of the study was insufficient to determine the relative importance of each mechanism, which may depend on drought duration, drought severity, and grass species and cultivars within a species.

\section{Conclusions}

In summary, variation in drought resistance among the tested seashore paspalum cultivars is documented in this study. As drought intensified, paspalum cultivars exhibited reduced turf quality, reduced ET and TE, reduced RLD, reduced MRE, reduced TRM, decreased TNC, increased RSC, and increased proline content. 'Salam' demonstrated greater drought resistance when compared with 'Excalibur' and 'Adalayd'. Turf mowed at lower mowing heights was more sensitive to drought stress. The resistance of paspalum cultivars to moderate to high drought stress can be enhanced by increasing the mowing height that may be related to increased carbon fixation, which favors increased root production. Also, proline accumulation could add to the drought tolerance through osmoregulation or by acting as a carbon and $\mathrm{N}$ sink for stress recovery.

\section{Literature Cited}

Arunyanark, A., S. Jogloy, C. Akkasaeng, N. Vorasoot, T. Kesmala, R.C. Nageswara Rao, G.C. Wright, and A. Patanothai. 2008. Chlorophyll stability is an indicator of drought tolerance in peanut. J. Agron. Crop Sci. 194: $113-125$.

Ashraf, M. and M.R. Foolad. 2007. Role of glycine betaine and proline in improving plant abiotic stress resistance. Environ. Expt. Bot. 59:206216.

Ashraf, M. and P.J.C. Harris. 2004. Potential biochemical indicators of salinity tolerance in plants. Plant Sci. 166:3-16.

Bañuelos, J., J.L. Walworth, P.W. Brown, and D.M. Kopec. 2011. Deficit Irrigation of Seashore paspalum and bermudagrass. Agron. J. 103:1567-1577.

Bates, L.S., R.P. Waldren, and I.D. Teare. 1973. Rapid determination of free proline for water stress studies. Plant Soil 39:205-207.
Beard, J.B. 1982. Turf management for golf courses. Burgess Publ. Company, Minneapolis, MN.

Beard, J.B. 1989. Turfgrass water stress: Drought tolerance components, physiological mechanisms, and species-genotype diversity, p. 2328. In: Takatoh, H. (ed.). Proc $6^{\text {th }}$ Int. Turf. Res. Conf., Tokyo, Japan. 31 July to 5 Aug. 1979. Jpn. Soc. Turf. Sci., Tokyo, Japan.

Beard, J.B., R.L. Green, and S.I. Sifers. 1992. Evapotranspiration and leaf extension rates of 24 well-watered turf-type Cynodon genotypes. HortScience 27:986-998.

Brosnan, J.T. and J. Deputy. 2009. Preliminary observations on the traffic tolerance of four seashore paspalum cultivars compared to hybrid bermudagrass. HortTechnology 19:423426.

Chatterton, N.J., J.H. Bennett, and W.R. Thornley. 1987. Fructan, starch, and sucrose concentrations in crested wheatgrass and redtop as affected by temperature. Plant Physiol. Biochem. 25:617-623.

DaCosta, M. and B. Huang. 2006. Minimum water requirements for creeping, colonial, and velvet bentgrasses under fairway conditions. Crop Sci. 46:81-89.

Dudeck, A.E., S. Singh, C.E. Giordano, T.A. Nell, and D.B. McConnell. 1983. Effects of sodium chloride on Cynodon turfgrasses. Agron. J. 75: 927-930.

Duncan, R.R. 1999. Environmental compatibility of seashore paspalum for golf course and other recreational uses. II. Management protocols. Intl. Turfgrass Soc. Res. J. 8:1216-1230.

Duncan, R.R. and R.N. Carrow. 1999. Turfgrass molecular genetic improvement for biotic/ edaphic stress resistance. Adv. Agron. 67:233305.

Ebdon, J.S. and A.M. Petrovic. 1997. Relationship between turfgrass quality performance and evapotranspiration rate in cultivars of kentucky bluegrass. J. of Turf Mgt. 2:1-12.

Flowers, T.J., P.F. Troke, and A.R. Yeo. 1977. The mechanism of salt tolerance in halophytes. Annu. Rev. Plant Physiol. 28:89-121.

Fu, J.M., A.J. Koski, and Y.L. Qian. 2005. Responses of creeping bentgrass to salinity and mowing management: Growth and turf quality. HortScience 40:463-467.

Green, R.L., S.I. Sifers, and J.B. Beard. 1991 Evapotranspiration rates of eleven zoysiagrass genotypes. HortScience 26:264-266.

Hays, K.L., J.F. Barber, M.P. Kenna, and T.G. Mc Collum. 1991. Drought avoidance mechanisms of selected bermudagrass genotype. HortScience 26:180-182.

Huang, B. 2008. Mechanisms and strategies for improving drought resistance in turfgrass. Acta Hort 783:221-227.

Huang, B., R.R. Duncan, and R.N. Carrow. 1997. Drought-resistance mechanisms of seven warmseason turfgrasses under surface soil drying: II. Root aspects. Crop Sci. 37:1863-1869.

Huang, B. and J. Fry. 1999. Turfgrass evapotranspiration, p. 317-334. In: Kirkham, M.B. (ed.). Water use in crop production. Food Products Press, New York, NY.

Huffman, A.R. 2004. The connection: Water and energy security. June 2013. <http://www.iags. org $/ \mathrm{n} 0813043 . \mathrm{htm}>$.

Jiang, Y. and B. Huang. 2001. Drought and heat stress injury to two cool-season turfgrasses in relation to antioxidant metabolism and lipid peroxidation. Crop Sci. 41:436-442.

Keeley, S.J. and A.J. Koski. 2001. Dehydration avoidance of diverse Poa pratensis cultivars and cultivar groups in a semi-arid climate. Intl. Turfgrass Soc. Res. J. 9:311-316.
Kim, K.S. and J.B. Beard. 1988. Comparative turfgrass evapotranspiration rates and associated plant morphological characteristics. Crop Sci. 28:328-331.

Kopec, D.M. 1985. Tall fescue soil moisture depletion, evapotranspiration and growth parameters. $\mathrm{PhD}$ diss., University of Nebraska, Lincoln, NE (Diss. Abstr. 85-26596).

Kramer, P.J. 1980. Drought stress and the origin of adaptations, p. 7-20. In: Turner, N.C. and P.J. Kramer (eds.). Adaptation of plants to water and high temperature stress. John Wiley \& Sons, New York, NY.

Krans, J.V. and J.B. Beard. 1975. The effect of clipping height and frequency on several physiological and morphological responses in 'Merion' kentucky bluegrass. Agronomy Abstracts. 67:100.

Lee, G.J., R.N. Carrow, and R.R. Duncan. 2008a. Identification of new soluble sugars accumulated in a halophytic seashore paspalum ecotype under salinity stress. Hort. Environ. Biotechnol. 49:13-19.

Lee, G.J., R.R. Duncan, and R.N. Carrow. 2002. Initial selection of salt tolerant seashore paspalum ecotypes. USGA Turfgrass and Environmental Research Online 1:1-7.

Lee, G.J., R.R. Duncan, and R.N. Carrow. 2004b. Salinity tolerance of seashore paspalum ecotypes: Shoot growth responses and criteria. HortScience 39:1143-1147.

Lee, G.J., R.N. Carrow, and R.R. Duncan. 2004c. Photosynthetic responses to salinity stress in halophytic seashore paspalum genotypes. Plant Sci. 166:1417-1425.

Lee, G.J., R.N. Carrow, R.R. Duncan, M.A. Eiteman, and M.W. Rieger. 2008b. Synthesis of organic osmolytes and salt tolerance mechanisms in Paspalum vaginatum. Environ. Exp. Bot. 63:19-27.

Levitt, J. 1980. Salt stresses, p. 365-454. In: Responses of plants to environmental stresses. Vol II. Academic Press.

Marcum, K.B. 2002. Growth and physiological adaptations of grasses to salinity stress. In: Pessarakli, M. (ed.). Handbook of plant and crop physiology. 2nd Ed. Marcel Dekker, Inc., New York, NY.

Marcum, K.B. and C.L. Murdoch. 1990. Growth responses, ion relations, and osmotic adaptations of eleven $\mathrm{C} 4$ turfgrasses to salinity. Agron. J. 82:892-896.

Nobel, P.S. 1988a. Environmental biology of agaves and cacti. Cambridge University Press, New York, NY.

Nobel, P.S. 1988b. Principles underlying the prediction of temperature in plants, with special reference to desert succulents. In: Long, S.P. and F.I. Woodward (eds.). Symposia of the Society for Experimental Biology. Number XLII.

Peacock, C.H. and A.E. Dudeck. 1985. Physiological and growth responses of seashore paspalum to salinity. HortScience 20:111-112.

Popp, M. and N. Smirnoff. 1995. Polyol accumulation and metabolism during water deficit, p. 199-215. In: Smirnoff, N. (ed.). Environment and plant metabolism. Flexibility and acclimation. Bios Scientific, Oxford, UK.

Qian, Y.L., J.D. Fry, and W.S. Upham. 1997. Rooting and drought avoidance of warmseason turfgrasses and tall fescue in Kansas. Crop Sci. 37:905-910.

Richardson, M.D., G.W. Chapman, C.S. Hoveland, and C.W. Bacon. 1992. Sugar alcohols in endophyte-infected tall fescue under drought. Crop Sci. 32:1060-1061.

Salaiz, T.A., G.L. Horst, and R.C. Shearman. 1995. Mowing height and vertical mowing frequency 
effects on putting green quality. Crop Sci. 35: 1422-1425.

SAS Institute. 2006. SAS/STAT user's guide. SAS Institute, Cary, $\mathrm{NC}$.

Shahba, M.A. 2010a. Comparative responses of bermudagrass and seashore paspalum cultivars commonly used in Egypt to combat salinity stress. J. Hort. Environ. and Biotech. 51:383390.

Shahba, M.A. 2010b. Interaction effects of salinity and mowing on performance and physiology of bermudagrass cultivars. Crop Sci. 50:26202631.

Shahba, M.A., S.F. Alshammary, and M.S. Abbas. 2012. Effects of salinity on seashore paspalum cultivars at different mowing heights. Crop Sci. 52:1358-1370.

Shahba, M.A., Y.L. Qian, H.G. Hughes, A.J. Koski, and D. Christensen. 2003. Relationship of carbohydrates and cold hardiness in six saltgrass accessions. Crop Sci. 43:2148-2153.

Sharp, R.E., T.C. Hsiao, and W.K. Silk. 1990. Growth of the maize primary root at low water potentials. II. Role of growth and deposition of hexose and potassium in osmotic adjustment. Plant Physiol. 93:1337-1346.

Shearman, R.C. 1986. Kentucky bluegrass cultivar evapotranspiration rate. HortSci. 21:455-457.

Suplick-Ploense, M.R. and Y.L. Qian. 2005. Evapotranspiration, rooting characteristics, and dehydration avoidance: Comparisons between hybrid bluegrass and kentucky bluegrass. International Turfgrass Society Research Journal 10:891-898.

Thomas, H. 1990. Osmotic adjustment in Lolium perenne; tts heritability and the nature of solute accumulation. Ann. Bot. (Lond.) 66:521-530.

Torello, W.A. and L.A. Rice. 1986. Effects of $\mathrm{NaC} 1$ stress on proline and cation accumulation in salt sensitive and tolerant turfgrasses. Plant Soil 93:241-247.

Trenholm, L.E., R.R. Duncan, and R.N. Carrow. 1999. Wear tolerance, shoot performance, and spectral reflectance of seashore paspalum and bermudagrass. Crop Sci. 39:1147-1152.

Turner, N.C. 1986. Crop water deficits: A decade of progress. Adv. Agron. 39:1-51.

Turner, R.M., S.M. Alcorn, S. Olin, and S.A. Booth. 1966. The influence of shade, soil and water on saguaro seedlings establishment. Bot. Gaz. 127:95-102.

White, R.H., M.C. Engelke, S.J. Morton, and B.A. Ruemmele. 1992. Competitive turgor maintenance in tall fescue. Crop Sci. 32:251-256.

Zinn, S. 2004. Suggestions for the care of seashore paspalum. Courtesy of Environmental Turf., Avon Park, FL. June 2013. <http://www. environmentalturf.com> 